\title{
LIFE AS READING: RAZUMOV'S INTERPRETATIVE SITUATION IN UNDER WESTERN EYES
}

\author{
Joanna Kurowska \\ Independent scholar
}

\begin{abstract}
This essay analyzes the interpretative situation of Razumov, the main hero of Conrad's novel Under Western Eyes (1910). Challenged by a fellow student named Victor Haldin, Razumov must navigate through his internal experiences (past, present, and those anticipated by him in the future), as well as through external stimuli-which he has little experience to understand fully-in order to arrive at morally meaningful decisions. Communicative aspects of Razumov's encounters, first with Haldin, then with his sister Natalie, are discussed in greater detail; particularly Razumov's use of speech and silence, first to conceal but ultimately to reveal the truth.
\end{abstract}

Keywords: interpretative situation, cognitive prejudice, community, tradition, the symbol of stranger, communication, speech, silence, moral choice

"Such evil could not occur unless someone caused it."

Augustine

According to The Oxford Illustrated History of English Literature, Conrad's novel Under Western Eyes (UWE) “conducts an implicit dialogue with Dostoevsky's The Possessed, its only rival as a fictional enactment of revolutionary consciousness; Conrad, as an anti-Russian Pole, had an inevitably complicated attitude to Dostoevsky's great novel" (Bergonzi, 404). Notwithstanding its valid references to two important lines in critical interpretation - the investigation of the relationship between Conrad and Dostoevsky and the reading of Under Western Eyes as a psychological study of "revolutionary consciousness"- the sentence evokes a stereotype implying that Conrad was anti-Russian because he was a Pole. Ironically, the statement also illustrates an important aspect of the narrative of Under Western Eyes, namely its intrinsic theme of the interdependence between cognitive dogmatism (stereotyping being one of its forms) and interpretation; as well as moral consequences of the interaction between the two. The consequences are moral because both inter- 
pretation and dogmatism are depicted in the novel not as abstract, theoretical concepts but as human attitudes and actions capable of influencing relationships between people, of causing pain or joy.

This essay endeavors to demonstrate that Under Western Eyes depicts precisely the complex nature of the cognitive process leading, through interpretation, to a morally significant choice. Such cognitive process is referred to as an interpretative situation. In an interpretative situation, words, signs, and symbols act on a person's consciousness and compel him/her to respond. This essay will explore the main constituents of the interpretative situation of Razumov, the novel's protagonist. Further, the interdependence between Razumov's interpretative situation and his ability to communicate with other people, will be discussed.

Kirylo Sidorovitch Razumov, a university student in Petersburg, makes two morally significant choices. The first is to betray Victor Haldin, a fellow student and revolutionary, who seeks refuge at Razumov's lodgings after assassinating Minister of State Mr. de P.-. The second is to confess the betrayal to Haldin's sister Natalia and to a group of revolutionaries in Geneva. The two choices frame the novel; the betrayal opens the plot, the confession closes it. It is assumed that Razumov's moral decisions are indeed choices; in other words that he is their sole actor and that he could act differently.

To outline the constituents of Razumov's interpretative situation, as they appear shortly before the betrayal, this essay will explore Josiah Royce's image of human individual as the center of a sphere. According to Royce, "every man inevitably finds himself as apparently occupying the centre [sic] of his own universe." Such cognitive point of view is both necessary and misleading, for it simultaneously "distorts [and] suggests the true nature of things" (Philosophy of Loyalty $[P L]$ 77). Considering that people live in time, it seems helpful to cut "the sphere" in half and show the human self as the center of a circle representing temporal rather than spatial aspects of his/ her perspective:

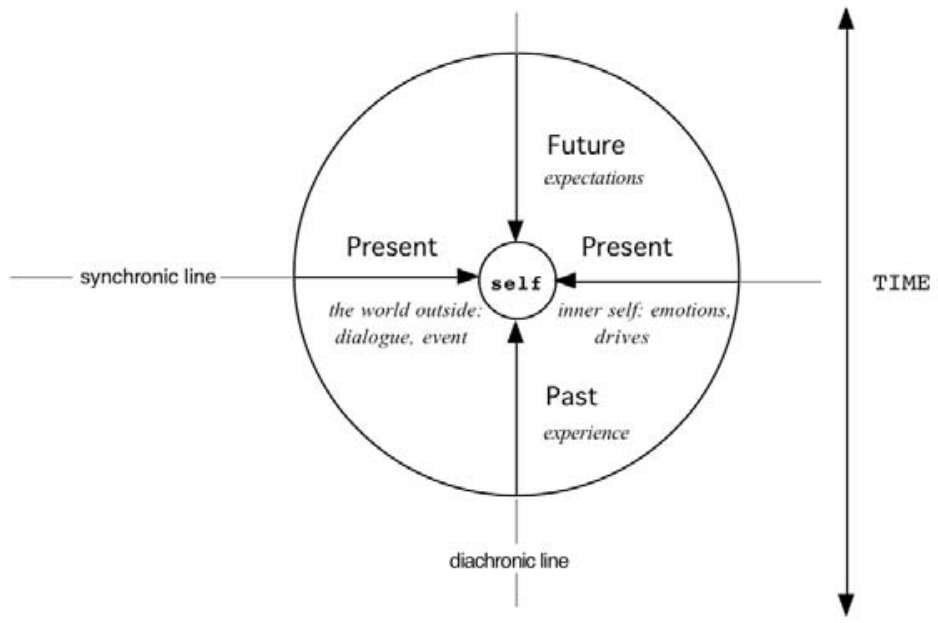

Source: The diagram by Joanna Kurowska. 
Individual consciousness becomes the converging center for a multitude of impulses, ideas, hopes, and experiences. Each of the four lines within the circle represents a number of impressions acting upon a person's consciousness in a given moment. The diagram represents a non-static situation because the configuration of the "lines" changes from moment to moment, and so do the relationships between the lines and their constituents. As Dilthey has observed, "everything which pertains to mind is interrelated: interconnectedness is, therefore, a category originating from life" (151). The responses of an individual to the impressions are the person's actions. A conscious action is preceded by an assessment of the situation, recognizing its constituents, an insight into their mutual relationship, and an examination of the challenges of the ongoing event.

The lines indicating future and past (the vertical line) and present (the horizontal line) are labeled with the Saussurean terms "diachronic" and "synchronic." Saussure used the terms to describe language. The interpretative situation represented by the diagram requires from the individual an activity similar to that required in dealing with language: the recognition and interpretation of signs and symbols. The complexity of one's interpretative situation exceeds systematic attempts to describe it, hence the diagram does not represent a fixed scheme but rather aims at depicting the interpretative situation as an "ongoing process of approximation and overcoming error by dialectically moving towards truth" (Gadamer, "Hermeneutics of Suspicion" 322). With this in mind, subsequent elements of Razumov's interpretative situation will be analyzed, his past, present (external and internal), and future.

The information regarding Razumov's past prior to his meeting with Haldin is scanty. His origin as the illegitimate son of an aristocrat and of an Archpriest's daughter symbolically makes him the product of the union of the State and the Church. He was raised in "an educational institute where they did not give [their pupils] enough to eat" (UWE 100). Not knowing any "domestic tradition" (ibid.) or love (332), Razumov is unable to acknowledge any experience as shared by a community. Considering the possibility of betraying Haldin he asks, "by what bond of common faith, of common conviction am I obliged to let that fanatical idiot drag me down with him?" (82). He does not know anyone of whom he could say, "this person comes from the same canoe" (cf. Philosophy of Josiah Royce [PJR] 64).

People overcome solipsism by expanding individual consciousness through identification with "events of past and future" shared by a community (cf. ibid.). The most elemental human community is family. Razumov acknowledges this indirectly, asking Haldin: "Did it ever occur to you how a man who had never heard a word of warm affection or praise in his life would think of matters on which you would think first with or against your class, your domestic tradition - your fireside prejudices?" (UWE 100). The excerpt discloses Razumov's intuitive knowledge of the significance of communal ties, and his attitude towards "domestic tradition," which he summarizes as prejudice. Since Razumov is a student of philosophy, his use of the term "prejudice" should be examined with closer attention. According to Davis, professors of philosophy in Russian universities "tended more or less to function as disciples of some Western masters" (157). In fact, "rationalism was well known among Russian 
intellectuals" and Razumov was likely to be "familiar with Voltaire, Rousseau, and the Encyclopedists" (156). His use of the word "prejudice" suggests a connection with the Enlightenment. Having decided to betray Haldin, Razumov ponders: "What can the prejudice of the world reproach me with?" (82). By the "prejudice of the world" he apparently means religious and moral traditions scrutinized during the Enlightenment, whence the word "prejudice" acquired negative connotations. As Gadamer observes, the Enlightenment's critique of prejudice was "directed against the religious tradition of Christianity," particularly against authoritarian interpretations of the Bible. Often the critique was "taken to the extremes of free thinking and atheism" (Truth and Method 272).

The surname "Razumov" additionally ties the protagonist with the Aufklärung. The Russian noun "razum" means "reason"; and reason was the Enlightenment's leading idea. Razumov's personality fully justifies the symbolic content of his name. He frequently boasts of his "cool superior reason" (UWE 80) and proclaims the "superiority of the thinking reed over the unthinking forces" (122). He does not "believe in another world" and favors order in both social and private life: "Better that thousands should suffer than that a people should become a disintegrated mass" (79). Due to the circumstances of his life, Razumov's only ties are with the State and its ideology. "I have no domestic tradition," he confesses (italics added). To fill the void he adheres to the one tradition with which he is familiar (most likely from lectures at his university), that of worship of human mind: "My tradition is historical, I am a man with mind" (100). Since rationalism is a tradition of "hostility towards tradition" (cf. Davis, 166), Razumov debunks tradition as "prejudice" but in doing so he deprives himself of the possibility of anchoring himself in a tradition. He ends up by upholding "the most important tradition of rationalism, the fight of reason against superstition and arbitrary authority" (cf. Popper, 188). As a result, he is entangled in the paradox pointed out by Gadamer: the Enlightenment's aim of "overcoming of all prejudices" itself became a prejudice ${ }^{1}$ (cf. Truth and Method 276). This paradox skews the cognitive process of Razumov-the thinker, so that he finds himself helpless in a challenging moment of his life.

Exercising reason proves to be an insufficient response to the complexities of the interpretative situations depicted in Under Western Eyes. It misleads Victor Haldin, a believer in the final victory of reason, who prophetically speaks of the coming of "the day of thinkers" (70). Haldin turns to Razumov because he trusts the latter's mind: "Speaking to a superior mind like yours I can well say all the truth" (67). Elsewhere Haldin describes Razumov as a man "head and shoulders above common prejudices" (97). On his part, Razumov constructs his idea of self through conquering knowledge understood as "theories, systems, speculations" (UWE-MS, qtd. in

\footnotetext{
${ }^{1}$ Cf. also Royce's assessment that "one of the most familiar traits of [modern] time is the tendency to revise tradition, to reconsider the foundations of old beliefs, and sometimes mercilessly to destroy what once seemed indispensable" (PL 273). A good example of this can be found in Jacques Derrida's Specters of Marx. After deconstructing the three "messianic eschatologies," Judaism, Christianity, and Islam, as waging a "ruthless war ... against each other" in the Middle East (58), Derrida—un homme moderne par excellence - ends up resurrecting Karl Marx, thus supplying a tradition in place of a tradition.
} 
Carabine, 8). Despite his declaration, "History-not Theory" (UWE 104), he is intellectually and spiritually anchored in theory, a fixed system with universal claim rather than in history as the unique, irreversible process of human experience. Ultimately, reason too misleads Razumov, for its dogmas leave him unprepared to face the moral complexities engendered by Haldin's intrusion. The appearance of Haldin does not fit the rationale of Kirylo's orderly life. Feeling "utterly confounded" (64), he ponders "the horrible discord of that man's presence" (69).

Razumov's lack of definite ties with any tradition (and thus with a past other than that of his immediate self) implies the absence of one of the main constituents of the interpretative situation. Plans for the future absorb Kirylo Sidorovitch almost entirely: "I must get acknowledged in some way before I can act at all" (100). For Razumov being acknowledged means achieving a high status in society. He believes that "a man's real life is that accorded to him in the thoughts of other men" (63). This way, the future becomes an alibi for refusing to respond adequately to the challenges of the present. Again, the lack of ties with the past hinders Razumov's ability to recognize properly the external aspects of his present. On the day of Mr. de P.-'s assassination, when the entire population of Petersburg talks about nothing else, Razumov resolves "to have a good try for the silver medal" (ibid.).

Apparently, Kirylo Sidorovitch's life is governed by only two sides of the circle delineating his interpretative situation, that of the internal present and that of the future. As to the former, Razumov's main drive is ambition, which results in that he neither accepts his present status (and thus his present self) nor recognizes properly the surrounding reality. As a rootless man he has to "create" himself anew by exercising reason. He accepts the existing order as "given" and treats it instrumentally: "His main concern [is] with his work, his studies, and with his own future" (61). He envisions the future as that of his academic and professional success: "A celebrated professor [is] a somebody Distinction [will] convert the label Razumov into an honoured name" (63). Consequently, he ignores anything that could impede his plans: "living in a period of mental and political unrest, he [keeps] an instinctive hold on normal, practical life" (61) and forgets "the dangers menacing the stability of the institutions which gave rewards and appointments" (ibid.).

The narrative mentions that Razumov "was aware of the emotional tension of his time" and "even responded to it in an indefinite way" (ibid.). However, such an "indefinite response" was hardly sufficient, and Kirylo's awareness heightens his responsibility for trying to live a healthy life in an unhealthy time, an attempt doomed to fail. Constructing in his conscience justifications to betray Haldin, Razumov observes "despotic bureaucracy... abuses... corruption... and so on" but transports the responsibility for solving those ills into the future, more precisely to "the great autocrat of the future" (80). Strangely enough, this reasoning resembles Haldin's. Both Kirylo and Victor use their respective eschatological visions of the future to justify their present conduct. Haldin employs revolutionary ideology to excuse violence; Razumov turns to autocracy "for the peace of [his] patriotic conscience," excusing his own cowardice and indifferent attitude towards the abuses of which he is well aware. Both Razumov and Haldin "sacrifice ... the present to ... a future that depends 
on the violent removal of social and ideological contradiction" (Raval, 139). One should mention that Haldin's involvement implies a level of self-sacrifice of which Razumov is not yet capable.

Razumov's lack of ties with the past and his refusal to face the problems of the present impair his ability to interact with other people. With regard to the horizontal line of his interpretative situation, indicating "the world outside him" (social relations and contemporary events), Razumov leads a solitary life. Though occasionally he visited "other students' houses," his presence at those meetings was most likely that of a "detached individual" practicing "relatively independent doings" against "confused activities of a crowd" (cf. Royce, PJR 361). However, during the course of his conscious life Razumov must have encountered symbols and signs that are part of common cultural heritage. As Dilthey observes, people live surrounded by "manifold forms in which what individuals hold in common have objectified themselves in the world of senses" (155). Those "manifold forms" constitute the world of objective mind understood as a set of "life expressions" of the human community at large. From this "world of objective mind the self receives sustenance from earliest childhood" (ibid.). Hence, life- expressions exceed the scope of a person's individual experience. They preserve the power of turning groups into communities. Thanks to the existence of traditions, symbols, and other expressions of the objective mind (be it laws, religious systems, etc.) we have anything in common. As the "words of culture," life-expressions are utterances of a Thou, similar to sentences in language. According to Dilthey, "a sentence is intelligible because a language ... is common to a community" (156). Indeed, tradition, which "expresses itself like a Thou," is language; a "Thou is not an object; it relates itself to us" (Gadamer, Truth and Method 358).

Whether Razumov is aware of it or not, various life-expressions surround him and remain within his reach. Among them, particularly important is the symbol of the stranger. The symbol appears frequently in "myths, legends, folktales and in literature as a whole," as "the one destined to replace the reigning power in a country or locality." It also stands "for the possibility of unseen change, for the future made present, or for mutation in general" (Cirlot, 315). In European culture, the symbol recurs in several traditions, particularly religious ones, as well as in folk cultures of the Slavs. With regard to religions, from "primal" pantheistic to "modern" monotheistic, the perception of the symbol of the stranger displays a gradual switch from fear and hostility, through awe and appreciation, to recognition and love. Tribes traditionally (if inadequately) referred to as "primitive" perceived strangers as something "brutish, monstrous, devilish" or "miserable or unfortunate" (Hamilton-Grierson, 884). Certain tribes viewed strangers as directly connected with the supernatural (887). The Hebrews recognized strangers' "sacred right to protection" (HamiltonGrierson, 893), as guaranteed in the Noachide law. In the Hebrew Scriptures strangers are often God's messengers. Genesis for example speaks of Abraham's encounter with three travelers, whom he treats with hospitality, while they bring him the message about Sarah bearing a child (Gen 18:1-2). The right of a stranger to hospitality was recognized in antiquity. In The Odyssey, the daughter of king Alkinoös, Nausikaa 
tells Odysseus: "But now, since it is our land and our city that you have come to/ you shall not lack for clothing nor anything else, of those gifts/ which should befall the unhappy suppliant on his arrival" (Homer, 107). In The New Testament the motif of the stranger assumes a particularly powerful meaning. In Matthew, the King of Heaven, after offering his kingdom to the "blessed ones," explains that he has done it because "I was hungry and you gave me food; I was thirsty and you gave me drink; I was a stranger and you entertained me; naked and you clothed me; sick, and you looked after me; in prison, and you visited me" (25:34-40; italics added). After the "blessed ones" ask the King when they saw him, he answers: "I assure you, insofar as you did it to one of the least of these brothers of mine, you did it to me." The symbol of the stranger is present in Slavic cultures, including Conrad's native Poland": "If a Slav refuses to receive a stranger, he is deprived of his property and his house is burnt down" (Hamilton-Grierson 893).

The symbol of the stranger well illustrates the process through which symbols acquire "memory." They last within human culture and through their agency the past becomes present in the "objective mind" or "mental context" of a given contemporaneity (cf. Dilthey, 156-161). The addressees of those symbols are human beingspersons, who remain at the center of their interpretative situations. Appearing as "utterances from the past," the symbols are also part of his/her consciousness, for "man is a product of the traditions surrounding him, of groups whose cohesion is based on solidarity to which he belongs" (Habermas, 135). At the same time, people encounter the traditions from without, through the ever-changing contact with their external present. Ideally, the present, the past, and the future modify one another. To paraphrase Josiah Royce, a person's idea of self in the present is an interpretation of that person's past, which ties with an interpretation of his/her "hopes and intentions" regarding the future (cf. PJR 360).

The richness of human culture and the complexity of one's interpretative situation, in which consciousness is subject to various impressions, require one's awareness and openness to new interpretations. A symbol does not present itself in a fixed, unalterable meaning; it cannot be perceived mechanically. While approaching a person's consciousness, it retains its acquired meaning or "memory." As it enters the complex realm of one's interpretative situation, it resembles an utterance in the realm of language: "The word, directed toward its object, enters a dialogically agitated and tension-filled environment of alien words, value judgments and accents, weaves in and out of complex interrelationships, merges with some, recoils from others, intersects with yet a third group" (Bakhtin, 276).

\footnotetext{
${ }^{2}$ The symbol of the stranger is central to one of Poland's popular myths, that of Ziemowit (pronounced Zhem'oveet), the legendary founder of the Piast dynasty. According to the myth, on the day of Ziemowit's postrzyżyny (ritual first haircut), two travelers, "weary, and travel-stained," approached the Piasts' humble cottage. Ziemowit's parents, who were simple farmers, received the strangers with hospitality. The travelers cut their son's hair and predicted that the child and his descendants would "rule for centuries." They also miraculously multiplied food in the Piasts' pantry (cf. Anstruther, 36-40. Ziemowit is mentioned, as the 10th-century founder of the Piast dynasty, in the Latin chronicle Gesta principum Polonorum, ca. 1116, by Gallus Anonymus). The Polish "sacred law of hospitality" resounds in the popular proverb, "Gość w dom, Bóg w dom" ('With a guest, God enters the house'), as well as in numerous customs.
} 
Depicting the circumstances of Haldin's intrusion into Razumov's life, Conrad seems to have employed precisely the symbol of the stranger. Haldin comes unexpectedly, late in the evening: "gleaming in the dusk, stood a strange figure, wearing a skirted, close-fitting, brown cloth coat strapped round the waist" (UWE 64). Confessing his crime, Haldin addresses Razumov as "brother" and literally puts his fate in the latter's hands. Scholars have interpreted Haldin as "the forces of irrationalism and discord" (Rado, 84-5); an "embodiment of History" (Humphries, qt. in Rado, 84); a "disruption," a "threat to metaphysical safety of every man" (Gekoski, 156); but in addition to being a harbinger of change, Haldin, as the symbolic "stranger," is also a vulnerable human being. Significantly, Razumov ignores Haldin's humanity while referring to his already-executed visitor as "it": "Fatality enters your rooms while your landlady's back is turned; you come home and find it in possession bearing a man's name, clothed in flesh. It asks you, 'Is the outer door closed?"- - and you don't know enough to take it by the throat and fling it downstairs" (UWE 118). Elsewhere, Razumov calls Haldin a "pest" or "pestilential disease" (77).

"Victor Haldin is not the only stranger Razumov encounters. On his way to the "eating- house," where he hopes to find Ziemianitch - the sleigh-driver whose help Haldin needs to escape - he meets a number of people from "the quarter of the very poor" (ibid.) The narrative informs us that the passersby "came upon [Razumov] suddenly, looming up black in the snowflakes close by, then vanishing all at once-without footfalls" (73). Among them is "an elderly woman tied up in ragged shawls," who "hugs under one arm a round loaf of black bread with an air of guarding a priceless booty" (ibid.). Razumov envies her peace of mind but it does not occur to him that someone for whom a loaf of bread is a "priceless booty" is less fortunate than himself. The woman's presence challenges the view of Razumov as "more entirely alone than any other character in all of Conrad's fiction" (Gekoski, 155). He is never so completely alone as not to encounter those, who are even more alone and in want. Razumov then visits the eating-house, "a monumental abode of misery on the verge of starvation and despair" (UWE 75), where an array of "bleary unwashed faces [are] turned to his direction" (74). In a stable next door he finds Ziemianitch, who is intoxicated and in despair. Once again, Kirylo proves to be unprepared to face the unexpected. Enraged by losing his only chance to get rid of Haldin, he brutally beats the helpless, stiff-drunk Ziemianitch. Razumov's violence signifies more than an uncontrolled emotional response to the unforeseen obstacle. In Ziemianitch, he sees the people: "That was the people. A true Russian man!" (77). Razumov is indifferent to Ziemianitch's misery and personal tragedy. Beating the man, he embodies the punitive, autocratic State, which aggravates the misery of its subjects rather than relieving it. Razumov believes people are children in need of masters: "Ah, the stick, the stick, the stern hand," he dreams, while "longing for power to hurt and destroy" (cf. ibid.).

Kirylo Sidorovitch's encounters with the "miserable of this world" culminate in his vision of Haldin in the snow. The phantom lies "out of the way a little, as though he had selected that place on purpose. The snow round him was untrodden" (81). Kirylo, who considers human beings as powerless "bladders" or "insignificant grains" (79), walks right across of the phantom's chest, with a "stern face, without a check 
and gazing far beyond the vision" (81). With its recurring motif of undisturbed snow (to emphasize the insignificance of the "miserable of this world"), the scene symbolically completes Razumov's series of encounters with strangers. He continues to walk "with lowered head, making room for no one" (80). There is no place for another man in the life of Kirylo Sidorovitch Razumov, the student of philosophy.

Conrad seems to employ symbols from common human heritage in such a way as to warn us against perceiving them habitually. For this purpose he uses defamiliarization, "removing objects from the automatism of perception" in order to "make the familiar seem strange" (Shklovsky, 13). By placing "the familiar" in an alien environment, Conrad reflects the complexity of a morally significant action, which involves assessing quid pro quos in one's interpretative situation. For example, Conrad makes the notorious de P.- turn towards the crowd after the explosion of the first bomb, with the words: "For the love of God, I beg of you good people to keep off." The second bomb strikes the Minister "on the shoulder as he stooped over his dying servant" (UWE 60). De P.-'s words and gesture indicate that the feeling of mercy was not alien to him. While (presumably) "evil," at the time of immediate danger he seems to think more about the safety of the casual bystanders than of his own.

The equivocality of symbols presented in Under Western Eyes reflects the "difficulties inherent in human freedom, of the terrible demands of 'moral' life" (Gekoski, 27). Aware that cognitive and moral aspects of human life are intertwined, Conrad continuously challenges the existing stereotypes regarding "words of culture." $\mathrm{He}$ appeals for a continuous "creative reorganization of an existing cognitive inventory" (Habermas, 125). The diagram representing a person's interpretative situation aims at demonstrating the dynamics of such reorganization and indicating that both synchronic and diachronic elements are involved. One may ask, how can a person in a given interpretative situation be aware of all the meanings historically accumulated in a given symbol? How can one analyze and interpret all the complex life-expressions in a situation demanding immediate response? A given interpretative situation is largely the fruit of past interpretative situations. Filtered through the channel of the present, a new experience confronts the person's past and throws new light on it, eventually producing "more comprehensive knowledge or insight" (Marshall, 42). An experienced person is prepared to face the unexpected, reconsider his/her past, and hence remain open to new experience. If - as in Razumov's case - a person's cognitive habits degenerate into a fixed scheme (dogmatism), anything new that does not fit must be eliminated or altered to fit the scheme.

Openness to the unexpected and the ability to rethink "the existing cognitive inventory" are "the virtues of the mind" and as such need to be cultivated. While, as Gadamer points out, the Enlightenment fell into the trap of the covert "prejudice against prejudice," Karl Popper cautions us against the "prejudice against the prejudice against a prejudice" (cf. "The Defense of Rationalism"). Admitting that rationalism stems from the irrational faith in reason, he differentiates between comprehensive (uncritical) rationalism, and critical one, whose merit lies in adoption of a "common medium of communication, a common language of reason," which ties with the "belief in the unity of mankind" inherent to critical rationalism (Popper 43). 
Josiah Royce too upholds the idea of the "unity of mankind" and praises loyalty to a community as a congenital human need to "serve the cause of unifying the lives of various human beings into one life" (PL 252). As the case of Razumov and Haldin demonstrates, individual loyalties (causes) may clash with one another, so that one's beliefs (values) need to be reconsidered in light of the beliefs and values of another. According to Royce, to remain faithful to the "unity of superhuman life" (cf. 357), a person must strive for loyalty to the "universal human cause" (ibid.).

Unlike Popper, Royce's scope of rethinking embraces religions, which are "endlessly rich in legend and in other symbolic portrayal" (390). He argues that, enduring through many ages (cf. 397), religious symbols are "due to all sorts of historical accidents" (391), which makes them "vary from place to place and from one nation or race of men to another" (397), as they become appropriated in various branches within the comprehensive quest for truth. Because of this, symbols require constant rethinking, to reveal ultimately "the living truth of the personal and conscious and ethical unity of the world" (ibid.). Ignoring the richness of human culture or disposing of its parts through stereotyping, are signs of cognitive laziness. As a result, as Dostoevsky put it in The Idiot, people "classify themselves according to appearances, and fail to find anything in common" (25).

Sometimes symbols are difficult to understand, which engenders the need "for an interpretation through some other mind" (Royce, PJR 390). When interpretive efforts fail, one's cognitive alertness leaves room for an interpreter. As Royce emphasizes, "in the order of real time the events of the world are signs [that] are followed by interpreters, or by acts of interpretation which our own experience constantly exemplifies" (ibid.). Since both the interpreter and the learner are immersed in their respective interpretative situations, the communication between them requires that they share a common language and display the will to understand each other. They both must be aware of the fact that "in thinking of the real world [one is] indeed thinking of the whole ... system of experience, in which [one's] experience is bound up, and ... an individual [has] a very limited and narrow place" (cf. Royce, PL 365). Even when one person willingly accepts the authority of another, both the "master" and the "disciple" must be aware of their own cognitive limitations (prejudices) and remain open to rethinking of their personal "cognitive inventories." The final choice, if it is to be a real choice, belongs to the learner, not to the master (though of course teachers often acquire new insights from their disciples, thus too being perpetual learners).

If Haldin embodies the symbolic stranger, he represents a particularly challenging version of the symbol. Having resolved that his self-sacrifice for the sake of the repressed Russian people would not go beyond certain limits - "We [the revolutionaries] have made the sacrifice of our lives, but all the same I want to escape if it can be done" (UWE 68) - he wronged Kirylo by involving him without asking for consent. Haldin's political programme, including the murder of de P.-, is controversial to say the least, certainly from Razumov's point of view. The latter makes a feeble attempt to question Haldin's trust: "But pardon me, Victor Victorovitch. We know each other so little... I don't see why you..." (67). Haldin seems to have presumed the existence of a shared moral order, on which he based his hope for Razumov's help. However, 
as Habermas observes, "for a norm to be valid, [its] consequences and side effects ... must be such that all affected [persons] can accept them freely" (120). This statement highlights two fundamental aspects of one's interpretative situation in the present. First, to be able to make a morally significant decision, a person must have the freedom to do so; second, if more than one person is involved, every participant must accept the validity of a given moral norm. For such a consensus to be possible, the confrontation between all the participants must take the form of a communicative situation, which constitutes a particular aspect of interpretative situation. During Razumov's encounter with Haldin, both conditions, that of freedom and that of consensus, were absent.

Life abounds in unexpected encounters and the "coordination of the action plans" as well as "free acceptance of the validity of a moral norm" may be difficult to carry out. Hence, Gekoski's assessment that "in allowing Victor Haldin to go free Razumov would not have been condoning the man's action, but simply behaving humanely to a fellow creature" (167) seems somewhat too easy a dismissal of Razumov's moral dilemma. In autocratic Russia people are treated as "children" and "the stick" is the norm. To paraphrase Lenin's well-known statement, in such a world one's conduct is "moral" only if it contributes to the creation of autocracy. ${ }^{3}$ There is no consensus as to moral norms. Paradoxically, Haldin's arbitrary request also springs from the logic of no-consensus characteristic to autocratism. Following Habermas's idea, Haldin and Razumov should have sought "coordination of the action plans of various interacting participants on the basis of a shared definition of the situation," so as to "interpret a shared action situation in terms of their diverse plans and from different perspectives" (145). Neither Haldin nor Razumov undertake the effort to achieve such coordination. However, unlike Razumov Haldin is candid. Unjustified as his claims may be, he communicates them sincerely, in a language Razumov understands. In contrast, Razumov refuses to employ language for communication; instead, he uses it to conceal the truth. Parallel to his inability to recognize symbols, his lack of straightforwardness in speaking results from the distortions of his interpretative situation. A closer look at his use of language (including non-verbal forms of communication) shall elucidate this further. The narrative informs us that, prior to his meeting with Haldin, Kirylo "in discussion was easily swayed by argument and authority" (UWE 57). This suggests that he did not have strong political or ideological convictions; undoubtedly a merit in "a country where an opinion may be a legal crime visited by death." Due to his self-centeredness Razumov displays a peculiar lack of responsiveness. He is a listener "of the kind that hears you out intelligently and then-just changes the subject." Generally, he has been "looked upon as a strong nature - an altogether trustworthy man." Such opinions result from the fact that "amongst a lot of exuberant talkers" Razumov demonstrates a "comparatively taciturn personality" (ibid.). Paradoxically, he wins trust of some among his fellow students because he never expresses his views. As the narrative informs us, prior to their fateful encounter after the death of de P.-, Razumov and Haldin once discussed with

3 "Communism" in the original statement. 
each other "first principles dear to the sanguine minds of youth" (64), on which (principles) they both agreed.

Haldin's visit "utterly confounds" Razumov but he "adopts the tone of hospitality." He listens without protestations to Haldin's misdirected compliments about his (Razumov's) "generosity of sentiments," "solidity of character," and "courage" (ibid.). A few moments later Haldin concedes that he has just killed de P.- and asks for Razumov's help in getting away. Dismayed by Haldin's actions, enraged by their underlying ideology, Razumov remains silent. The danger Haldin brings is real but considering that he has "met no one on the stairs" (65), Kirylo could refuse and send him away. Also, Haldin mentions "Another," a co-participant in assassinating de P.-. Since that man was killed in action (cf. 66), once the police found his body, the "Another" was likely to be taken for the sole assassin. The case would end, Razumov's life would return to balance.

If silence prevails in Razumov's initial response to Haldin, the situation changes after the betrayal. After his return from the authorities, Kirylo becomes loquacious. Whereas previously he made use of the "ambiguous nature of silent communication," with its potential for misunderstandings (cf. Jaworski, 68), presently he employs speech as a "deterrent to and terminator of communication" (8). In other words, he speaks with the purpose of concealing the truth. He quickly realizes it is a difficult task: "A diabolical impulse to say, 'I have given you up to the police" frightened him exceedingly" (UWE 95). From this moment on he finds himself continuously "on the edge of betraying himself when he is talking to another character" (Hawthorn, 108). Silence becomes his enemy and must be muffled with words: "The silence had lasted a long time ... He could resist no longer. He sprang to his feet, saying aloud, 'I am intolerably anxious"' (UWE 97). Haldin's quiet attitude makes Razumov uneasy. "What move is he meditating over so quietly ... He must be prevented. I must keep on talking to him" (100).

Razumov experiences mixed feelings of pleasure and horror. The source of pleasure is the discovery that one can lie by speaking partial truth. He replies mockingly to Haldin's remark about the familiar stable, "That's where I had my interview with Ziemianitch ... It was satisfactory in a sense. I came away from it much relieved" (96). But the slippery nature of half-truths terrifies Razumov, "His forehead broke out in perspiration while a cold shudder ran down his spine. 'What have I been saying?' he asked himself. 'Have I let him slip through my fingers after all?"' (ibid.). Facing now another man, who remains in his own interpretative situation and has an "alien" perspective, Razumov finds himself on the unfamiliar ground of a communicative situation. In the state of mental torture, willy-nilly he arrives at the realization that "knowledge is obtained through words, the meaning of which has to be forged in use with other people" (Hawthorn, 116).

He must provide the unsuspecting Haldin with false information, a half-truth. To his dismay, the other responds. Reason - Kirylo's ally so far-does not suffice to deal with the irksome unpredictability of Haldin's response. Razumov is unaccustomed to the fact that "as one talks, one is reading the response of the person one is talking to" (Jaworski, 9). Haldin's utterances awaken in him various sensations. He gets "vexed 
with himself for attaching so much importance to what Haldin said" (UWE 98); becomes "frightened at [the other's] movement" (99); and feels "a wicked anger [getting] hold of him" (101). The necessity to respond to Haldin intensifies Razumov's torment, "This train of thought ... was succeeded by a paroxysm of silent hatred towards Haldin, so intense that Razumov hastened to speak at random" (98).

Kirylo Sidorovitch has no preconceptions regarding his visitor and does not care about him. Lacking ties with other people he has no clue how to "read" people, whereas Haldin, who is positively biased towards Razumov, misreads his host. The narrative depicts an odd confrontation between two seemingly different interpretative attitudes, one of a "cultivated resistance to understanding," the other of mis-understanding (cf. Burns, 115). Both result in the lack of communication. If being in an interpretative situation requires one's cognitive alertness towards words, signs, and symbols, such alertness is even more crucial in a communicative situation. As Dilthey observed, "knowledge of the mind-constructed world originates from the interaction between lived experience, understanding of other people, the historical comprehension of communities as the subject of historical activity and insight into objective mind" (151-2). Thus, Razumov is compelled to learn and accept the difficult "truth about the truth," as defined by Royce: "The truth is diversified by its relation to ... various personalities that live in ... the real world" (PL 78). Further, Kirylo Sidorovitch must "discover the limits of [his] knowledge, so that his own world and its presuppositions become in some respect questionable" (Marshall, 40). Finally, he has to realize that "the world as interpreted by [him] is a fact different from the world as interpreted by [another]" (PL 78).

Because communicative situation involves reading another person's utterances (cf. Jaworski, 9), various interpretations are possible, including a misreading. Observing that one's "understanding of what is written depends on what version of it [one is] reading, and this in tum depends on just when and where [one] is reading it, and with whom" (120), Burns portrays the nature of verbal communication as well. With its inherent possibility of choosing between at least two different meanings of a single utterance and the potential for a communicative action, the communicative situation inevitably evokes the problem of freedom. Razumov's cognitive dogmatism and his "cultivated resistance to understanding" limit his recognition and use of the free choice. This too is caused by the distortions of his interpretative situation, where he believes that "I have to act this way" because "there is no other way."

Again, Kirylo lives in a sociopolitical order in which exercising freedom of choice is dangerous. However, even in the conditions of severe limitations - political, social, material, or personal, a person remaining in his/her interpretative situation can exercise a level of freedom. This is best illustrated by a simile of a person sitting in a train. Once on the train, one cannot change its course and has to stay inside it until the destination. But there are still a number of things a person can do while in a trainsuch as reading, talking, thinking, counting, eating, looking through the window, singing, praying, drawing, dozing, writing, knitting, exercising, changing seats, studying, listening to music, etc. The train-simile illustrates the fact that even in a situation of limited choices subsequent interpretative situations bring about the pos- 
sibilities of a new recognition, interpretation, and action. Carrying within itself a truly explosive potential, every interpretative situation delineates the minimal infinity of our freedom. Recognizing those possibilities can help one to cultivate unbiased alertness and readiness to take individual responsibility in a morally challenging situation. Other than ultimate slavery, no system or dogma can waive this responsibility.

The development of Razumov's cognitive attitude, as depicted in Under Western Eyes, entwines with the growth of his moral and communal sensitivity. He knows that Haldin's visit has altered his life irrevocably: "when he got back into the middle of things they were all changed, subtly and provokingly in their nature: inanimate objects, human faces, the landlady, the rustic servant-girl, the staircase, the streets, the very air" (UWE 285). What really changed was Razumov's perspective, not things.

Kirylo's second critical moral choice takes place during his stay in Switzerland, where he arrives to spy on the Russian revolutionaries gathered in Chateau Borel in Geneva. While in Geneva, Razumov meets Haldin's sister, Natalia, with whom he falls in love. He soon receives news about Ziemianitch's suicide. Convinced that he was responsible for Haldin's execution, the unfortunate sleigh-driver hanged himself. This circumstance is advantageous to Razumov, for it protects him from being found out. Now he is free to marry Haldin's sister (cf. 333). He visits Natalia's mother to inform her about Ziemianitch's alleged involvement in her son's death. Bumping into Natalia, he suddenly finds himself in a new interpretative situation, "her presence in the ante-room was as unforeseen as the apparition of her brother had been" (cf. 318). Still remembering the lie he has just recited before Natalia's mother, Kirylo ponders with a "sinking sensation," "Must I repeat that silly story now?" Razumov's ensuing decision to confess the betrayal of Haldin to Natalia reflects his painstaking process of coming to truth: "Because I always did know [the truth]." The "strong sense of Natalia Haldin's presence" (ibid.) dissipates the "dull, absent obstinacy" (319) from Kirylo's expression, as he gradually comes "to himself in the awakened consciousness." More ready now to experience another person's influence, he opens up to empathy: "Natalia Victorovna? You have been able to cry?" (ibid.); "Have no fear. It is not to betray you" (326). He also begins to communicate his feelings: "That does not mean that [my heart] is insensible. ... It is not as hard as a stone" (320).

Gradually, "the truth begins to struggle on Razumov's lips" (cf. ibid.). His love for Natalia compels him to confess his role in Haldin's demise. On this new path "from the blindness and hate" (cf. 333) to moral freedom, he also finds it necessary to confesses the truth to the revolutionaries. In putting his fate in the hands of others he now resembles Haldin. One of the revolutionaries metes him a blow, which makes Razumov's eardrums burst. Hit by a tramcar on his way home, Kirylo suffers severe injuries. Deaf, crippled, and dependent on other people, ${ }^{4}$ he returns to Russia (cf. 347). Lisa Rado argues that because of Kirylo Sidorovitch's deafness his existence "degenerates into an absurd" (92). However, the exact opposite seems to have taken place. Razumov's life has progressed from absurd to tragic. As a deaf man-now sharing the fate of those who "leave no footfalls on the snow" (UWE 73)-Kirylo

${ }^{4}$ In Russia, he is taken care of by Tekla the Samaritan. 
receives visitors. By their accounts, "he is intelligent ... has ideas [and] talks well, too" (347). Spurred by the challenges he encountered in his interpretative situations, followed by his actions, the moral development of Kirylo Sidorovitch Razumov has completed the full cycle, from transgression to atonement, to reconciliation with human community.

\section{WORKS CITED}

Anstruther, F. C., Old Polish Legends, New York: Hippocrene Books, 1991.

Augustine, On Free Choice of the Will, transl. T. Williams, Indianapolis: Hackett, 1993.

Bakhtin, M., Speech Genres and Other Late Essays, transl. V. W. McGee, eds. C. Emerson, M. Holquist, Austin: University of Texas Press, 1986.

Bergonzi, B. [in:] The Oxford Illustrated History of English Literature, ed. P. Rogers, Oxford: Oxford UP, 1990, pp. 379-430.

Burns, G. L., Inventions: Writing, Textuality and Understanding in Literary History, New Haven: Yale UP, 1982, pp. 11-24.

Campbell, C. A., "Has the Self 'Free Will'?” [in:] J. Perry, M. Bratman, J. M. Fischer, Introduction to Philosophy: Classical \& Contemporary Readings, New York: Oxford UP, 1986, pp. 447-56.

Carabine, K., "The Figure behind the Veil: Conrad and Razumov in Under Western Eyes" [in:] Joseph Conrad's Under Western Eyes: Beginnings, Revisions, Final Forms. Five Essays, ed. D. R. Smith. Hamden: Archon Books, 1991, pp. 1-38.

Cirlot, J. E., A Dictionary of Symbols, $2^{\text {nd }}$ Edition, transl. J. Sage, New York: Philosophical Library, 1971.

Conrad, J., Under Western Eyes, New York: Penguin Books, 1985.

Davis, R., "Crossing the Dark Roadway: Razumov on the Boulevard des Philosophes [in:] Joseph Conrad 's Under Western Eyes: Beginnings, Revisions, Final Forms. Five Essays, ed. D. R. Smith, Hamden: Archon Books, 1991, pp. 155-73.

Derrida, J., Specters of Marx: The State of the Debt, The Work of Mourning \& the New International, transl. P. Kamuf, New York: Routledge, 1994.

Dilthey, W., “Awareness, Reality: Time” [in:] The Hermeneutics Reader, ed. K. Mueller-Vollmer, New York: The Continuum Publishing Company, 1994, pp. 148-64.

Dostoevsky, F., The Idiot, transl. C. Garnett, New York: Bantam Books, 1981.

Gadamer, H.-G., "The Hermeneutics of Suspicion," Man and World 1984, no. 17, pp. 73-83.

-----, Truth and Method, $2^{\text {nd }}$ Edition, ed., transl. and rev. J. Weishaimer, and D. G. Marshall, New York: Continuum, 1994.

Gekoski, R. A., Conrad: The Moral World of the Novelist, New York: Barnes \& Noble Books, 1978, pp. $1-28$.

Habermas, J., Moral Consciousness and Communicative Action, transl. C. Lenhardt, S. W. Nicholsen, Cambridge: The MIT Press, 1996.

Hamilton-Grierson, P. J., "Strangers" [in:] Encyclopaedia of Religion and Ethics, ed. J. Hastings, New York: Charles Scribner's Sons, 1922, vol. XI, pp. 883-896.

Hawthorn, J., Joseph Conrad: Language and Fictional Self-Consciousness, Lincoln: University of Nebraska Press, 1979, pp. 94-128.

Homer, The Odyssey, transl. R. Latimore, New York: Harper Perennial, 1991.

Jaworski, A., The Power of Silence: Social and Pragmatic Perspectives, Language and Language Behaviors vol. 1., Newbury Park: Sage Publications, Inc., 1993. 
Marshall, D. G., "Reading as Understanding: Hermeneutics and Reader-Response Criticism," Christianity and Literature 1983, vol. 33(1), pp. 37-48.

Popper, K., Popper Selections, ed. D. Miller, Princeton: Princeton UP, 1985.

Rado, L., "Walking Through Phantoms: Irony, Skepticism, And Razumov's Self-Delusion in Under Western Eyes," Conradiana 1992, vol. XXIV(2), pp. 83-99.

Raval, S., The Art of Failure: Conrad 's Fiction, Boston: Allen \& Unwin, 1986.

Royce, J., The Philosophy of Loyalty, New York: The Macmillan Company, 1924.

, "The Problem of Christianity" [in:] The Philosophy of Josiah Royce, ed. J. K. Roth, New York: Thomas Y. Crowell Company, 1971.

Shklovsky, "Art as Technique" [in:] Russian Formalist Criticism: Four Essays, eds. L. T. Lemon, M. J. Reis, Lincoln \& London: University of Nebraska Press, 1965. 